\title{
高分子の音響材料
}

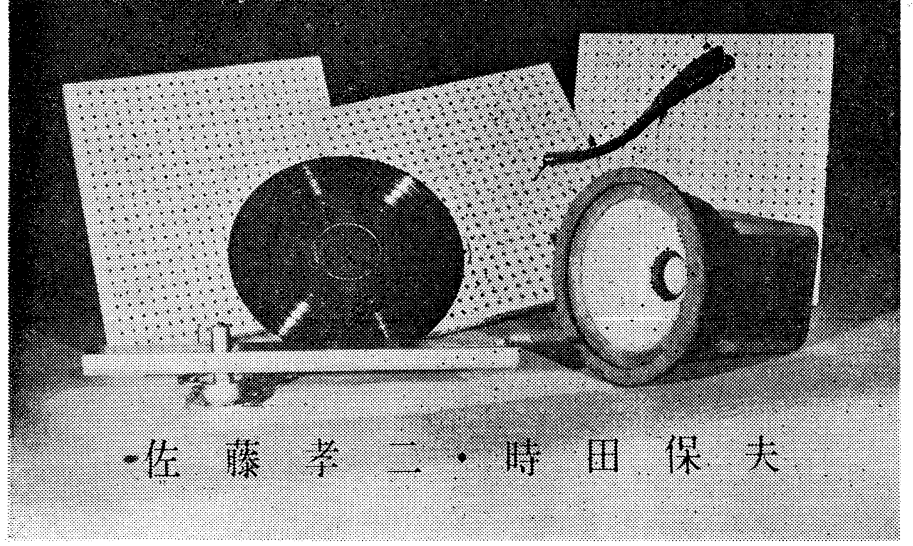

に壁や天井からの反射音もほとんど同時に耳 に達している。全然音を反射するものがない 場合は，廣い野原で音を聞くようなもので直 接音しか聞くことができず，極めてあっさり した感じであるが, 風呂場のように四方タイ ルのような反射物で覆われている部屋で声を 出すと, 声がよく響いて雄大な感じがするも のである。しかしあまり響きすぎるとビンビ ン響いて何をいっているか聞きとれない。そ れで室をつくる場合には適当に響かせて快い 感じで音が聞きとれるようにする必要があ る。昔は單なる経驗と製作者の直感によって つくられ,このよらな音響効果はあまり研究 されなかったのであるが, 最近は Sound Conditioning といら言葉と共にうるさくい われだし,多くの研究者もこの問題にたずさ

最近音に対する関心が大分高まってきて, 音樂堂の音 響設計, 都市に挍ける騷音対策, HiFi 再生など, 日常生 活での音の位置が向上してくると共に，それらに用いら れる材料の問題も多くの研究者によって研究されつつあ る。一般に高分子の音響材料といっても，材そのもの から纎維製品, 各種プラスチックス, ゴムなどの粘彈性 物質と非常に廣範囲にわたり, それら全般について述べ る知識も紙数も不足なので限られた項目について, 何の ために, どのような物が, どのよらなところに使われ， またどういう物が希望されているかという点について概 略を述べることにする。

これから述べる対称としては，音または 振動のエネルギーを吸收するのに用いられ るもの, 、わゆる吸音材料, 四振材料, ダン パーなどといわれている物について說明す ることにし，機器の筐体などに用いられる 合成樹脂, 樂器の材料となる木材, レコー ド，磁氣錄音テープに使われる高分子材料 など，音響に関係の梁い材料はあるが省略 することにする。

吸音材料, ダンパーなどを大別すると大 体, 纎維質材 (室內の壁, 天井などに張っ てあるテックス，カーテン類）と粘彈性物 質 (吸振, 制振に用いられるゴム, グリー ス，オイル類）とに大別することができる。 次にこれらについて簡單に說明を加えてゅ く。

\section{§1. 緎維質材料}

〔室內晋響〕われわれが部屋の中で音を 聞いているときは, 音源からの直接音の外 カット：吸音穴あきテックス，ピックアッ プ, スピーカー, レコード。
わっている。

室の中の音の聞きやすさの Measure になるものに残 響時間 (Reverberation Time) がある。これは室の中 で音の発生を停止してから, 室內の音のエネルギーが 10-6 になる迄の時間である。反射がなければ短く,よ く幛く部屋は残響時間が長い。快く聞くためには最適残 譥時間が必要である。また聞く対称によってこの最適值 がかわってくるものである。すなわちスピーチと音樂と では音樂の方が長い残響時間を必要とする。どの程度の 残譥時間が一番よく聞えるかということは古くから研究

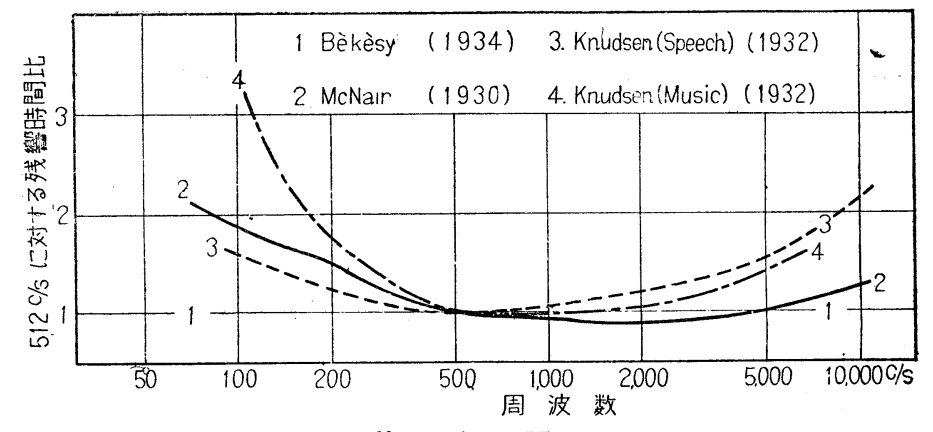

第 1 図

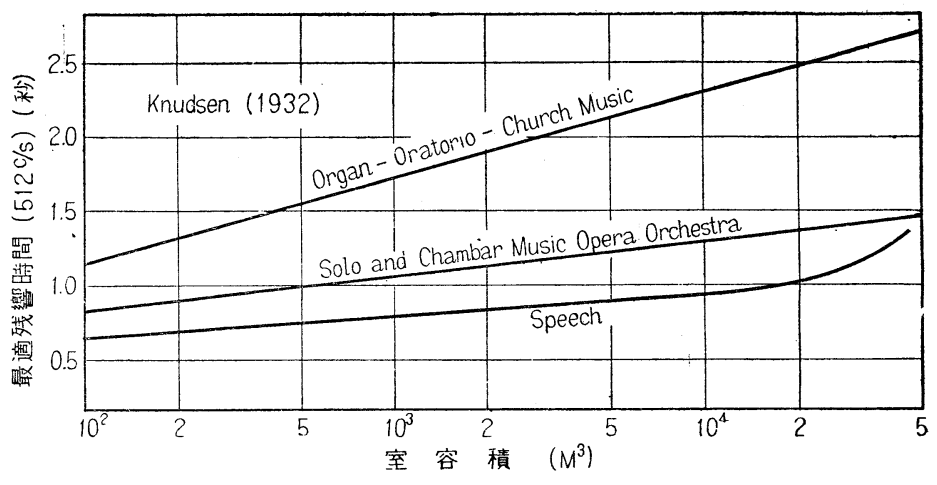

第 2 図 


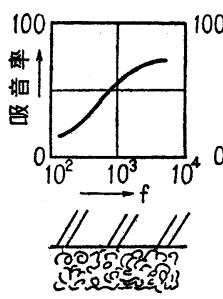

a. rigid porous

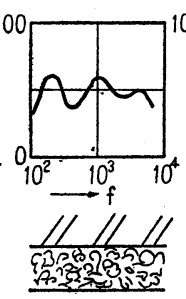

b. flexible
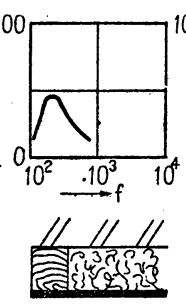

c. panel
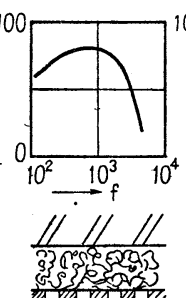

d. perforated panel

第 3 図

され，それぞれ権威ある研究者によって data が発表さ れている。その 1 例が第 1 図に示してある。橫軸が周波 数で縱軸は $512 \mathrm{c} / \mathrm{s}$ の残響時閒に対する比であらわして いる。また部屋の大きさによってこの最適時間が異な り, 第 2 図に室の容積と $512 \mathrm{c} / \mathrm{s}$ の最適残響時閒との関 係を示している。

これらの最適残響時閒を得るために，壁，天井，床な ぞに適当な吸音性を附加するわけで一般には繊維質材料 がよく用いられる。ロックウール，グラスウール系の無 機質瀻維材の進出は目ざましいものがあるが木材纎維類 の有機質瀻維材はこれらの発達のはじまりから, 現在も なお多く用いられている。床に用いられる羊毛䋐嘎，コ ルク,リノリューム，また壁に垂らすカーテン類はまず さておき, 壁の吸音の機構と現在使われているものにつ いて說明する。

壁の吸音の機構として基本的な型は第 3 図に示される ようなものであり，その吸音特性はおのおの各図に示さ れているようなものである。この縱軸情吸音率で入射エ ネルギーと反射エネルギーとの差を入射エネルギーで割 り1から引いたものの\%である。a のタイプは Acoustic Plaster または纎維のように，固い多孔性の骨組があっ て振動する空氣との摩擦によって熱エネルギーに変換さ れる機構である。振動数の高い方で有効で壁から少し離 すと低音でもかなりの吸音を示す。この機構では表面の 多孔性が極めて重大な意義をもつので, 表面平滑のもの より污れやすく，その欠点のないのが b 以下である。 b は一般に用いられているテックス類で, 表面自身はそ う porous でないが, flexible であるため內部摩擦でエ ネルギーを散逸させることができるし，また振動する空 氣との摩擦でも吸音する機構であり比較的廣い周波数に 対して有効である。 $\mathrm{c}$ はベニヤ板などの軽い構造の板を パネルに組んだもので, これは板が共鳴振動して板自身 の內部摩擦と固着部分でのエネルギー散逸により吸音す る。中に纎維類を入れて銳い吸收をおさえることができ る。この構造は比較的低い振動数に有効な吸音を示す。

$\mathrm{d}$ は戰後盛んに用いられるようになった機構で, いわ ゆる穴あき吸音壁とよばれるものである。パネル自身は あまり振動しないが，音波があたると穴と後方の空間で 生ずる共鳴で吸音するもので, 穴の大きさ, 数, 後方の

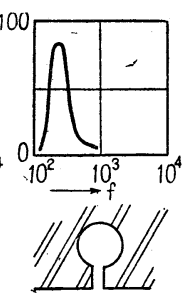

e. single resonator 周波数をずらすことがで
質吸音材料の吸音機構は $\mathrm{a} \sim \mathrm{d}$ である。

現用されているテックス類のうち有機瀻維質材に用い られているものはパルプ纎維系統と麦桿系統である。ま た表面被覆用として金銅に短繊維を吹き付けたものがあ る。最近ポリスチレン多孔板の非常に軽い壁材料が発表 された。現在は多くの会社で種々の製品をつくっている が，室內裝飾に重要な役割を果すものであるからこの方 が重点になり，特別吸暗性をよくしたものというのはな く, $\mathrm{d}$ の機構で構造上任意の周波数特性にもってゆくよ らに考えている。

䊼嘎，カーテン類に用いられるものはいずれも原理的 に a の type に属するものであり,その吸音率の 1 例を 次表に示してある。

\begin{tabular}{|c|c|c|c|c|c|c|}
\hline & 128 & $\begin{array}{r}\text { 振 } \\
256\end{array}$ & & 1024 & & 4096 \\
\hline Hair felt $(2.5 \mathrm{~cm})$ & 12 & 32 & 51 & 62 & 60 & 56 \\
\hline Jute felt $(1.3 \mathrm{~cm})$ & 5 & 8 & 17 & 80 & 52 & 51 \\
\hline Jute felt $(2.5 \mathrm{~cm})$ & 15 & 22 & & 63 & 57 & 52 \\
\hline 絨眊(パイラー 3 号) & 52 & 42 & 45 & 56 & 50 & 43 \\
\hline カーテン(ポプリン) & 23 & 24 & 28 & 39 & 37 & 15 \\
\hline カーテン(ドン ス) & 28 & 34 & 41 & 42 & 38 & 33 \\
\hline カーテン(ビロード) & 50 & 63 & 67 & 70 & 64 & 37 \\
\hline
\end{tabular}

〔無響室〕先に述べた室內に用いる材料は大きい吸音 率を特に必要とするものではないが，無響室に用いられ る材料はできるだけ大きい吸音率を示すものであってほ しい。無響室とは音響実驗をするときに，廣い野原のよ らに反射のない場所を再現するために室を全然反射のな いようにつくったものである。現在使われている無響室 は大別して 2 つに分けられ，1つはグラスウールを楔狀 につくったものを壁にたくさんはめ达んだものと，他の 1 つは週当な厚さの繊維質吸音層を壁から離して置いた 型のものである。後者の型の無響室に用いられている材 料はほとんど麻綿である。麻袋をほぐしたものを目の疎 、麻布で表面を覆い, $20 \mathrm{~cm}$ の厚さのものを壁から約 15 $\mathrm{cm}$ 離して裝着してある。吸音の特性は前項 $\mathrm{a}$ 亿該当 するものであり，高い振動数に対してはほとんぞ 100\% 吸音するが低、振動数（100 c/s 前後）では $50 \%$ 位に 
低下゙する。30 $25 \mathrm{~cm}$ の厚さで密度 $30 \mathrm{~kg} / \mathrm{m}^{3}$ 位の床綿 を壁から $15 \mathrm{~cm}$ 離したものは $100 \mathrm{c} / \mathrm{s}$ で $90 \%$ の吸音 率がある。層の厚さにより吸音率は変化するが厚くする ことによる吸音率の上昇と裝備の手間とのか放合から $20 \mathrm{~cm}$ 位の厚さが使われている。

この多孔性物質の吸音率を決める材料の性質として Porosity（穴あきの度合), Flow Resistance（空氣の流 動抵抗), Complession Modulus, Density などが関係し 研究者によってどのように吸音率にきいてくるか式を出 しているが決定的なものはない。しかし Porous で軽い ものといら條件は必要條件である。またこの種のものに ついては耐火, 耐濕性も要求されており, その点暊綿は 極めて要求に近いものである。

現在のところ天然繊維に賴っている現狀であるが，外 國で多泡性ビニル（スポンジゴムの類）で吸音曆をつく る試みが行われているが，穴が貫通することが大切で， 独立氣泡では効果なく未だ実用に供された例は聞いてい ない。吸音材料の基本的性質がわかってくると合成纎維 などの材料が淮出してくるのではないかと思っている。

\section{§ 2. 粘彈性物犋}

[防振材料]ここで防振材料といらのは, 機械の振動 を床に傳えないためのものとか，車輛の振動を軽減する ためのものなど，大きな振動を他に傳えないようにする ものに限定する。

この防振の原理は, 機械の使用時の振動数に対して, 機 械の質量と防振材の Stiffness で形成される振動系の共 振周波数を低くして振動の傳達率を下げることであり， これに加えて內部摩擦による発熱でエネルギーを散逸さ せるわけである。しかし現在主としてゴムが使われてい

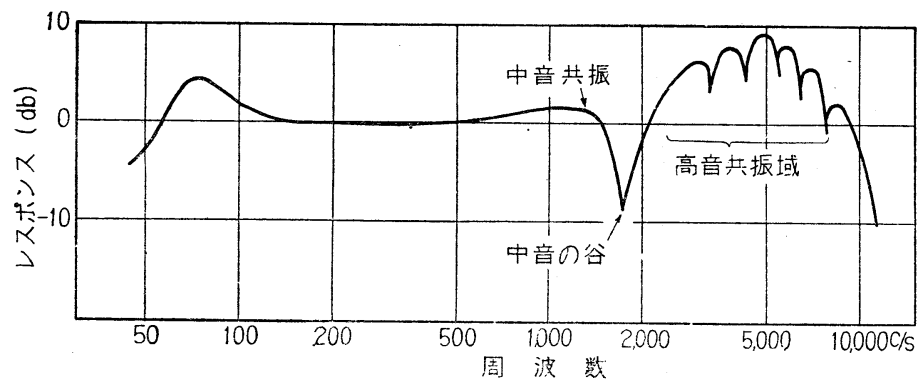

第 4 図

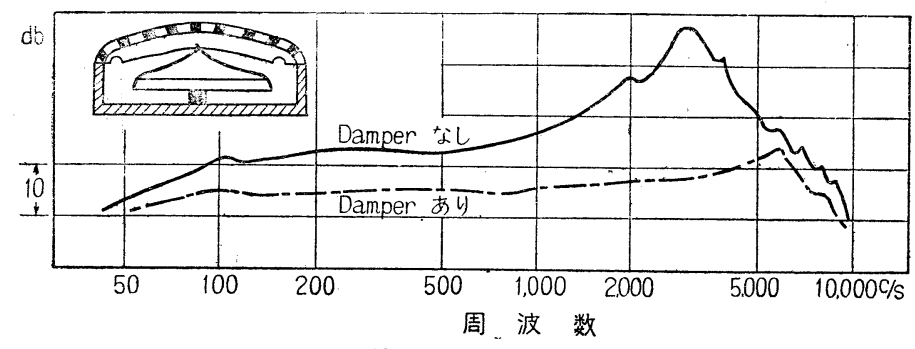

第 5 図
るのであるが, 振動振巾が大きいために発熱が著しく、ゴ ムを老化せしめてしまうので, むしろ內部摩擦の発熱の 少ないものが望まれている。シリコンゴムの発達はこの 方面で大いに期待されている。

〔制振材料〕ここで述べる制振材料とは, 電氣音響機 器（例えばスピーカ, マイクロホン, ピックアップな ど, 音 (または振動) を電氣的出力に変換したり, 電氣 的入力を音（または振動）に変換するもの）にいわゆる ダンパーと呼ばれて使用されているものである。これら の機器は振動系の集合体であるため, 数多くの共振点を 有する。この共振系に抵抗 (1 部バネも) を附け加えて 周波数特性を flat にするためにダンパーを用いるわけ である。音響機器では種々の方法で Damping を與えて いるが（機械采から電氣的に Feed back する方法, 空 氣の粘性抵抗を利用する方法, 粘彈性物質をつから方 法), その中粘彈性物質を使う方法は高分子化学の進步と 共に非常によく使われるようになってきた。ここではこ れについて若干述べることにする。

Damping Material としてはいかなる性質のものが望 まれるかといえば 1) Mechanical loss が大きいこと。 これはダンパーとしての必要條件である。2) 溫度によ る特性変化の少ないこと。昨今汽粘彈性物質のきらわれ ていた理由はこの溫度依存性が極めて大であったのが原 因であったが，最近シリコン系物質の進步により使用範 囲が廣くなってきた。3) 振巾および振動速度による Nonlinear のないこと。すなわち振巾が大きくなると 急に Loss がふえるとか, 速度との比例関係が速度が大 になると 2 乘, 3 乘で loss が起るなどといらことがない ことである。

次にいかなる場所にどのようなものが，ぞのようにし て用いられているかを簡單に說明する。

スピーカ：スピーカで使われている材 料でコーン紙は纎維質材料で, これ自体重 要な材料である。コーン紙は密度が小さく， ヤング率が大でまた內部 loss も比較的大 きなものが望まれている。スピーカの特性 をしらべてみると原則的に第 4 図のような 特性になる。

この図にあらわれている共振の中，中音 の谷はコーン紙の中心と緣との間に定常波 がのり位相が逆の振動となるために生ずる ものである。また高音共振域の山や谷はコ ーン紙に節振動の共振が生ずるためであ る。コーン紙の綠の Damping を大きくし て波の反射を少なくして定常波ののるのを 防ぐとか，節振動の起り難いように形をか えるとか, 加工の方法により Mechanical loss 大きくしたりして共振をおさえる 

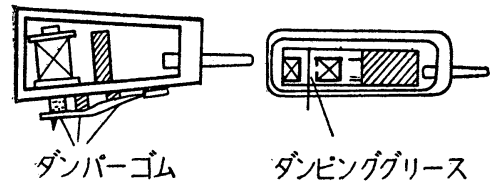

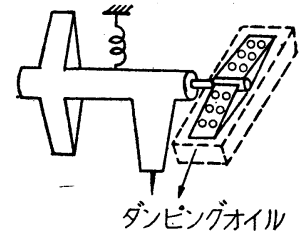

図

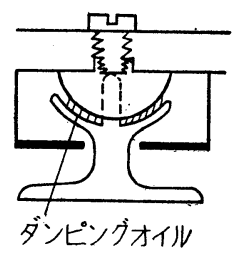

第 6

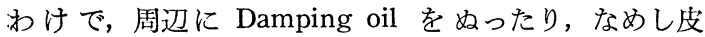
のようなやわらかいものでコーン紙とフレームを接続し たり，楕円コーンにしたり，紙に樹脂加工したりしてこ の共振を防ぐようにしている。

マイクロホン：現在マグネチック, ダイナミック, コ ンデンサマイクロホンでは粘彈性物質を使った例はほと んどない。クリスタルマイクについて簡單に說明する と, ロッシェル塩振動子に力を加えて電圧を取り出すも ので，振動子の共振のところで大きなピークが特性の上 にあらわれる。この共振を㧤さえるのにダンパーを用 い，支台に使らゴム，振動子にぬる粘性物質により特性 は非常に変化する。その 1 例が第 5 図である。

ピックアップ：クリスタルピックアップは原理的に前 述のマイクロホンと同じであるから省略し，マグネチッ クピックアップについて說明する。第 6 図で左側が Variable Relactance Type とよばれている型であるが これは 1 点支持の可撓片の針先の運動が出力となってで る。この可撓片に共振が起ると特性にピークが出るので 図のような位置にダンパーを挿入してある。中央は Floting Armature Type といわれているものであるが, 縱に立っている針の上辺を支点として運動し, 針先の運 動が出力となって出るので，前後の運動を針金でおさえ ると共に針のまわりにグリースをつめて Damping を與 えている。右の図はレコードをきざむ場合に用いるカッ ターの例であるが, Armature の一端をオイルの入った 函に入れて，オイルの流動抵抗を利用して Damping を
あたえている。またピックアッ プに用いているアームで，支点 の位置に Damping oil を入れ て運動を本滑にすると共に，ア ームを傳って來た振動を吸收す るようにつくられたものもあ る。一番右がその構造である。

材 料：以上の例に用いられている Damping Material はどのようなものかといえば，1）ゴム：これには 普通のゴム，シリコンゴムのほかに重金属とシリコンゴ ムとを混合したものなどがある。普通のゴムは溫度依存 性が大きいがシリコンゴムは溫度特性がよい。しかしシ リコンゴムの方が內部損失が少ないのでタングステンな ごの重金属を混ぜて金属粒子との相互摩擦でlossを增す ように試みて相当よい結果を得ているのもある。2) ビ スコロイド：これには液狀からゴム状固体迄あり，極 めてよい Damping を示すが溫度依存性が相当に大きい 欠点がある。3) ポリイソブチレン：これもよいダンパ ーであるが溫度特性が惡く牛流動性のため, シリコング リースと混合してそれを補っている例もある。4) シリ コンオイル：オイルダンパーとしては溫度特性がよく， 一般によく用いられている。

この他にも各機器会社ではダンパーをどうにするかと いら点で研究を重ねているようである。現狀としては前 に述べたような特性を満足するものの出現を望んでい る。

おわりに：以上非常に大ざっぱであるが，音響材料 のらち吸音材料, 防振材料, 制振材料について述べたが, 各項目で述べたように皆現狀では滿足していない。近年 高分子科学の発達にともなって種々の性質のものが合成 されるよらになってわれわれ音響材料をあつからものは 大いにその成果に期待しているわけである。

(小林理学研究所)

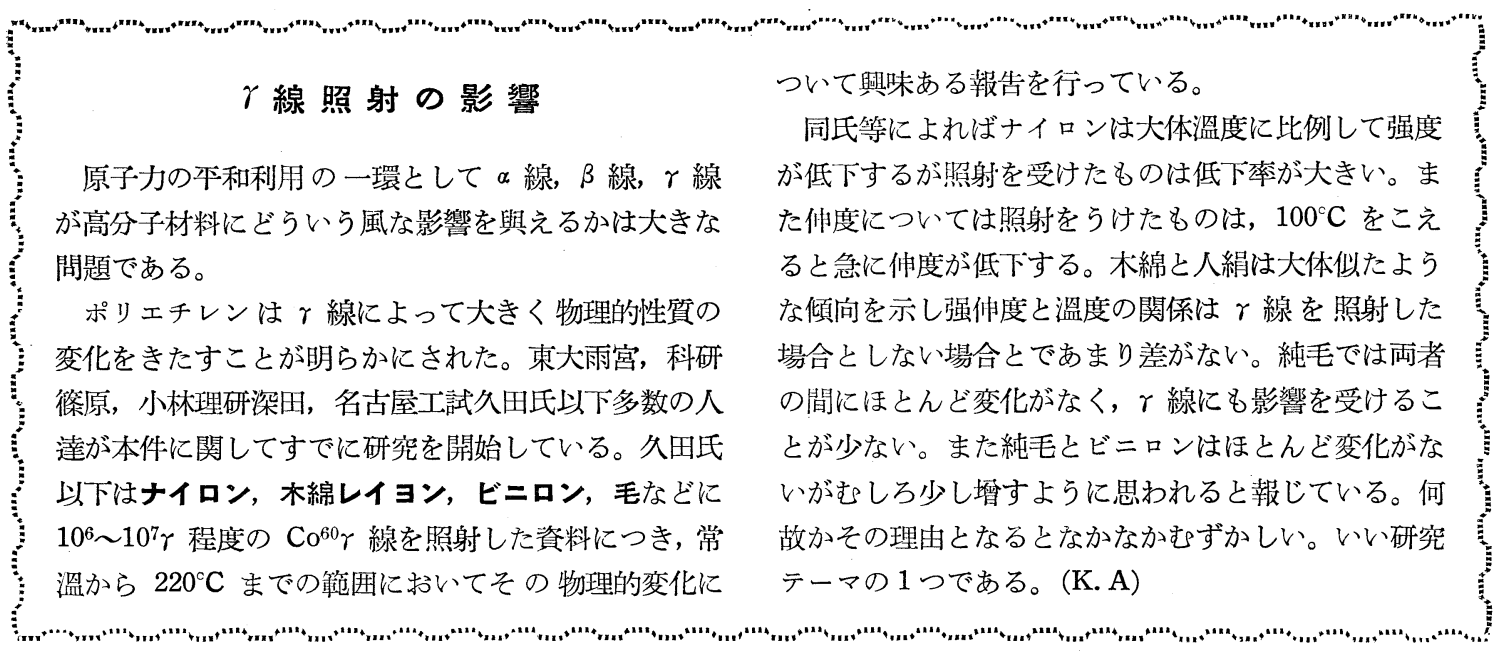

